\title{
PREPARING TOURIST SPACES FOR THE 2014 FIFA WORLD CUP THOUGHTS ABOUT DETERRITORIALISATION, RETERRITORIALISATION AND GENTRIFICATION ${ }^{1}$
}

\author{
Vicente de Paula Censi Borges* \\ Federal University of Piauí-Brazil
}

Norberto Santos**

University of Coimbra

\begin{abstract}
The present paper has to aim into territorial reflect changes in Rio de Janeiro -which hosted some of the games of the 2014 FIFA World Cup-, including the preparation of urban space for accommodating tourists and setting up the necessary sports infrastructure for the mega event, identified as tourist areas. Based on newspaper clippings on the subject from the Brazilian press and bibliographic research, the study research method used was exploratory, which made it possible to adopt a qualitative outlook. It was assumed that there is currently sufficient information on the 2014 FIFA World Cup. Consequently, it was possible to expand the scope to include the relevant variables in the case study, which cannot be quantified. Tools used to collect information included bibliographical and document research, which enabled the study to conclude that the process of urban replanning adjusted the area to the needs of the sports mega event. It also triggered the displacement of the communities living in the areas targeted for improvement and expansion of the necessary infrastructures, in many cases against the will of the dwellers, with the excuse that their
\end{abstract}

Fecha de recepción: 23 de julio de 2017.

Fecha de aceptación: 11 de junio de 2018.

* MA Tourism and Doctor of Tourism, Leisure and Culture from the University of Coimbra. CAPES/Brazil Grant, File No. 9984/13-5. Professor of Tourism Studies at Piauí Federal University. Address: Av. São Sebastião, 2819, Nossa Senhora de Fátima, 64202-020, Parnaíba, Piauí, Brasil. E-mail: vpborges@ufpi.edu.br

** Geographer and Doctor of Human Geography. Associate Professor, aggregate of the Department of Geography of the Faculty of Arts of the University of Coimbra and Researcher at the Centre for Geography and Land Planning Studies. Address: Colégio de São Jerónimo, Largo da Porta Férrea, 3004-530, Coimbra, Portugal. E-mail: norgeo@ci.uc.pt

1 This work was supported by National Funds from the FCT - Foundation for Science and Technology under the project "Pest-OE/GDSS/UI4084/2014" 
living conditions would improve, the risk of life would be reduced and appropriate housing would be guaranteed, while democratic access to goods and services was not expanded.

Keywords: 2014 FIFA World Cup; gentrification; tourist space; deterritorialisation; reterritorialisation.

Preparación de la zona turística para la Copa del Mundo de 2014: reflexiones sobre la desterritorialización, reterritorialización y gentrificación

\section{RESUMEN}

El presente trabajo se centrará en los cambios territoriales en Río de Janeiro -que acogió algunos de los juegos de la Copa Mundial de la FIFA 2014-, incluyendo la preparación del espacio urbano para acomodar a los turistas y la creación de la infraestructura deportiva necesaria para el mega evento, Zonas turísticas. Basándose en los recortes de prensa de la prensa brasileña sobre el tema, el método de estudio utilizado fue exploratorio, lo que permitió adoptar una perspectiva cualitativa. Se supone que actualmente hay suficiente información sobre la Copa Mundial de la FIFA 2014. En consecuencia, fue posible ampliar el alcance para incluir las variables relevantes en el estudio de caso, las cuales no pueden ser cuantificadas. Las herramientas utilizadas para recopilar información incluyeron investigación bibliográfica y de documentos, lo que permitió concluir que el proceso de replanificación urbana ajustó el área a las necesidades del mega evento deportivo. También provocó el desplazamiento de las comunidades que viven en las zonas de mejora y expansión de las infraestructuras necesarias, en muchos casos contra la voluntad de los habitantes, con la excusa de que mejorarían sus condiciones de vida, reducirían el riesgo de vida y Se garantizaría una vivienda adecuada, mientras que el acceso democrático a los bienes y servicios no se ampliara.

Palabras clave: Copa Mundial de la FIFA 2014; gentrificación; espacio turístico; desterritorialización; reterritorialización.

\section{INITIAL THOUGHTS}

There is a Portuguese saying that goes: "People have a short memory". This means in general that whatever a politician or anyone else does, either well-intentioned or not, is generally forgotten, thus granting them anonymity and, in time, the perception that they can act again in the same way.

Consequently, the work carried out by the Brazilian press (occasionally judgemental) is of such great importance, since it exposes important events that deserve being highlighted and remembered. It keeps the population informed over a longer period of time, fostering comparative analysis and criticism of past and present facts.

With this in mind, the years before the 2014 FIFA World Cup mega event, organised by FIFA - Fédération Internationale de Football Association and CBF - Confederação Brasileira de Futebol, received broad and unrestricted coverage by the national and international press, which produced news and influenced events, mostly in two ways, first by researching and reporting, secondly by playing the part of the producer of economic and social expectations. 
The present research starts from the premise that the national press played an important part in the sale, production and consumption of the 2014 FIFA World Cup event. Gaffney (2014:217) states that "the sale, production and consumption of sports mega events cannot be separated from their geographical-political-historical-economic-social context". Consequently, the message of a positive legacy influenced the nature of the idea sold to the local population, just as the image of the "country of football" marked commercial interests, fostering the rationale of intervention in public and private space to the detriment of the event itself and the needs of fans and tourists.

However, territorial change materialised more explicitly in the host cities; it was promoted by the neoliberal model of the federal, state and municipal governments, and in the case of the 2014 FIFA World Cup by public-private partnerships, either as concessions for exploiting property, goods and services or the privatisation thereof (Zimbalist, 2010; Clift, 2010 and Urani, 2009). It is therefore seen that the public policies, as underlined by Gaffney (2014), developed and implemented before and after the FIFA World Cup, favoured the private entrepreneurial sector and not so much the populations of the host cities. In other words, "public redistribution was disregarded in favour of the private regime of accumulation" (Gaffney, 2014: 217).

Such market dynamics, as it was considered, impacted the populations of the host cities, mostly in terms of the expectations of social and economic development it created. So, we ask: did the deterritorialisation, reterritorialisation and gentrification processes help to develop tourist space in relation to the 2014 FIFA World Cup mega event?

Slater (2003) highlights:

"I have advanced a step-by-step methodical critique of these studies, which are analytically defective when considered alongside Peter Marcuse's (1985) conceptual clarity on the four distinct forms of displacement in gentrifying neighborhoods: direct last-resident displacement, direct chain displacement, exclusionary displacement, and displacement pressure (...). It is no coincidence that those who have been pressing the view that displacement is negligible and that gentrification is not as troubling as the extensive literature suggests have all missed Marcuse. When conceptual verification is brought to bear on the declamatory discourse of the media reaction to this scholarship claims that gentrification is a panacea for abandonment and class/ethnic segregation become deeply problematic. Furthermore, the magnitude of dislocation taking place on the new frontiers of gentrification and displacement in the global (...) offers compelling evidence for an argument that intellectual and moral concerns over displacement must not dissipate at precisely the moment they are urgently needed on both scientific and political grounds".

Therefore, this paper has to aim to reflect the transformation of territory in Rio de Janeiro and the impact on the people, based on newspaper clippings and looking into the narratives of the Jornal do Brasil, O Globo and the magazine Veja, considering that the city had large sums of public and private investment for hosting some world cup matches.

Thus, this article discusses fundamental aspects for understanding the process of transformation of the territory in preparation for the Football World Cup 2014, such as the processes of deterritorialization in the city of Rio de Janeiro, gentrification of urban spaces and the reterritorialization of communities such as Vila do Recreio II. 


\section{THEORETICAL GROUNDS}

\subsection{From the Real Space to Tourist Spaces: Unique insight into Rio de Janeiro}

Described by the Brazilian and world press as the largest sporting challenge in the history of Brazil, not so much for the competition itself, but due to the size of the socialspatial infrastructural transformations, the 2014 World Cup sowed in the minds of Brazilian population the hope of inheriting a legacy of improved basic and support infrastructures, i.e. sanitation, access to electric power, quality public health, public security, public education, quality public transportation, roads, etc. However, the plan traced by the Brazilian government was hardly implemented, since a number of issues arose (delays in the construction of the football stadia, poorly designed infrastructures, etc.), which exposed the gaps in the initial plan.

In this turbulent context, the organiser of the FIFA World Cup and (federal, state and municipal) governments came up with a clear strategy, to reinforce the Brazilian identity, founded primarily on football, remembering the words of the writer, Nelson Rodrigues, "Brazil is a nation of football boots". In other words, to bring the sense of unity to the country that is marked by social diversity and the exclusion of a representative part of the population from the access to many goods and services.

In view of asserting the country's identity, built on the communication needed for promoting the event and the country itself as a tourist product ${ }^{2}$, the organisers sought to highlight, exalt and prepare certain features of the local culture, i.e. to create a specific environment representing the cultural reality that they wished to express.

Picking up on Darci Ribeiro's (1995) views, Brazilian identity, from an early stage, stood out for its unique features imposed by all kinds of variables, like the adjustment to local conditions, be it the environment or types of production, while maintaining "renewed genesis of the same matrix". Brazil is a culturally and socially multifaceted country that is influenced by lifestyles and world views from the European, African and indigenous cultures, expressed in a variety of traditions and beliefs.

Therefore, Brazilian identity in football gave the country's government the opportunity to unify the people around a common interest, considering the symbolic wealth found through and in football. However, in this respect, the process of constructing the image of the country in terms of sports and cultural tourism linked to large events was turned into the exposure of a part of the Brazilian culture in a given moment in time.

Mega events are known to produce limited impact on the timeline. In a framework of weak organisation, it can even work against the quality of life of the resident population, before and during such events, as a result of increased pressure on the access to goods and services if miscalculated.

According to Pappas (2014), residents do not perceive the negative impacts before a mega event, as they are numbed by the glorification of the potential benefits. Nevertheless, the opposite happened in Rio de Janeiro. The local communities understood the process of "whitening" space and blocking the access to the benefits produced during and after

2 Beni (2003, p.172) emphasises tourist product as " a set of goods and services manufactured in all sorts of economic units, which are aggregated in the market when their tourist charms are emphasised". 
the event. The resistance movement against the football mega event grew and continued, reflected in the displacements and delays in the schedules; this was the case of Porto Maravilha, where part of the territory know as "Little Africa" was captured by tourism, property speculation and infrastructure development that was not directed towards the resident population (Ribeiro, 2014).

So the unity that was aspired was not achieved. As was seen through the exposure and perception of the potential to attract visitors, in the case of the World Cup in Brazil, the desired cohesion was not fully achieved; not all social groups took part or identified themselves with the development of a single identity, also taking into account the population's views on public spending on the mega event, which in the minds of the people was money that was needed in other areas, like health and education. Citymarketing and implementation strategies were used in a Top -Down context of imposing large urban refurbishment projects (Gaffner, 2014), like Transcarioca, the reurbanisation of the surroundings of the Maracanã stadium and the modernisation of the multimodal station of that stadium.

For a better understanding of space, Santos (1997) highlights four indissociable dimensions: form, function, structure and process. Form means the visible part with the distribution of physical objects. Function is the activity for which form was designed. Structure results from the links between the parts and, last, process is related to time, in which continuous change is deeply rooted.

Applying Santos's (1997) views to tourism, Rodrigues (1999) reflected and summarised it in five fundamental elements of tourist space: people, companies, institutions, infrastructure and the environment. Understanding these elements helps to grasp the tourist phenomenon better, particularly intersectoral relations in a tourist destination.

Therefore, according to the understanding of space of Santos (1997) and Rodrigues (1999), the interaction between guest and host during the 2014 World Cup produced an unstable and fragmented environment. This rather meaningful situation resulted in restricted access of the population to services and space, in addition to public financing of the mega event and over-budgeting, which caused hard feelings against the sports event.

The tourist space in Rio de Janeiro developed for the 2014 World Cup mega-event took control of the use of urban space that was in the hands of few people. Harvey (2008) explains that, in similar contexts, there is a tight link between the development of the system of domination and urbanisation. Consequently, the urban redevelopment plan envisaged creating mobility and, in tourist terms, linking different tourist attractions of the city, maintaining the dynamics of space appropriation, and laying out new territories. In other words, the tourist space of Rio de Janeiro was implemented as "a consequence of the presence and territorial distribution of tourist attractions" (Boullón, 1997:65), and the creation of new attractions ${ }^{3}$.

Regarding the preparation of this scenario, where artificiality represents an attempt to build an authentic reality, it is important to highlight an environment that focuses on guest service. This perspective is explained by Santos e Gama (2008), quoting Debord (1991).

3 An example of new projects which arose as tourist attractions is the Museum of Tomorrow, which is part of an environment linking other points of interest. It is a tourist facility that anchors the urban revitalisation of the port area that is now called Porto Maravilha. 
Considering that tourist products occur simultaneously in tourist space and is perishable, one understands that the "show represents consumption, and production, integrating in society a consumption/show and, consequently the product in itself" (Santos e Gama, 2008: 117), awarding a special value to the capitalist ideology of profit.

Consequently, considering the need to satisfy tourists immediately, tourist space was enhanced under the World Football Cup event, through culture that was "artificially preserved" (MacCannell, 1992: 8) and recreated, limited to parts of the territory, fostered guest-host interaction, while developing tourist experience and the development of the cultural landscape.

MacCannell (1992 quoted by Grünewald, 2003) finds that the economic activity of tourism, like some others, helps "constructed or reconstructed ethnicity" to emerge. Therefore, to satisfy the motivation of travel and existing tourist demand, the relevant social groups, either indigenous of the location or not, seek to create and incorporate an atmosphere of authenticity (Table 1) of the cultural heritage exposed, producing an environment whose identity tourists see as authentic, but the natives do not. Or it is otherwise authentic to the natives, but with an "air" of artificiality which is characteristic of a culture that is "crystallised" in time, and does not show the signs of the history and the social dynamics of the place.

In the case of Rio de Janeiro, tourist space reflected the artificial authenticity, picking up on popular ideology of "Brazil, the country of football" or "Brazil, the country of carnival".

Table 1

\section{STATES OF AUTHENTICITY}

\begin{tabular}{|c|c|}
\hline \multicolumn{2}{|c|}{ States of authenticity } \\
\hline Real authenticity & $\begin{array}{c}\text { Circumstances are authentic and real and are perceived as such. They } \\
\text { usually take place outside of tourist areas. }\end{array}$ \\
\hline Staged authenticity & $\begin{array}{c}\text { Authenticity arising from the intervention and staging of tourist } \\
\text { facilities. }\end{array}$ \\
\hline Denial of authenticity & Real and authentic tourist spaces, whose authenticity tourists doubt. \\
\hline Invented authenticity & $\begin{array}{c}\text { Staged space, which the tourist perceives as staged. Example: staging of } \\
\text { traditional dances and shows. }\end{array}$ \\
\hline
\end{tabular}

Source: Cohen (1984 mentioned by Augusto, 2014)

Hence, tourist space represents the social environment that fosters crossed relations, founded on the complicity between guests and hosts, which encompasses the characteristics of the tourist, who is mostly motivated by the football mega event and the host's hospitality (Grünewald, 2003). In Rio de Janeiro, however, such cordial environment was worn down by the existing social and economic inequalities and people's perception of the priorities of capital needs, limiting tourists to tourist spaces.

Therefore, tourist spaces of the 2014 world cup were generally sectarian, particularly in the host cities. These were where the government and capital intervened to change and adjust space to the needs of sports and tourists, e.g. tourist tours and routes, football 
stadiums and their surroundings and the areas where tourists move around to get to the places they intend to visit or to the places where the matches are played, hereby promoting "ethnic cleansing4" under the territorial-urban redevelopment.

\subsection{Central issues: Tourism, Territory and Gentrification - Influences of the 2014 FIFA World Cup}

Historically, the development of cities, space formation in Brazil and populating the sparsely populated areas of the Brazilian countryside starting in the 1950s brought about social exclusion, which featured the process of deterritorialisation. Haesbaert (2010) describes deterritorialisation in the strict sense as taking control over the territory away from a social group, i.e. implementing reclusion and/or contention measures against the group. From another, although complementary, perspective, Haesbaert (2007) states that there is no deterritorialisation without reterritorialisation, which generates, in the author's mind, multiple territories.

Hence, the dynamics underlying the design of tourist and sport spaces in Rio de Janeiro and other host cities of the 2014 World Cup before the event and during the matches was understood as the consolidation of a trajectory that produced commercialising centralities of urban space (Ribeiro, 2014).

Rio de Janeiro became an environment of ongoing renewal of the meaning of space aligned with capital needs, throughout the preparation of the FIFA World Cup mega event, which is visible today. Excuses like the improved quality of life of the local population, urban and tourist mobility were given, but, conversely, barriers were raised to contain or manage the flow of people.

It is worth highlighting the viewpoint of Haesbaert (2010), who establishes three types of physical barriers (Figure 1) for monitoring and controlling a territory: a) barring wall - preventing the expansion and development of a neighbourhood; b) between wallscan cause the isolation of a district or community as a result of the expansion of another community; c) duct wall - contain corridors to avoid visual contact between passersby and residents.

The "construction of a city for tourists to see", specially cities where social inequality is present at points of tourist interest, involves three things: 1. Establishing movement points and points of tourist interest; 2. Diagnosing visual reality and infrastructure; 3 . Adjusting space to tourists' needs and wishes. Generally speaking, decision-makers and planners surprisingly agree with the above. They believe that the tourist image, and that of the promotion of the place, must replicate the image that tourists have, i.e. a representation of reality or of the desired landscape, which is probably not the original.

In the cities that hosted the 2014 FIFA World Cup, Rio de Janeiro in particular, during the seven years of preparation for the event, there was clearly a focus on the urban planning of some spaces in the cities and some projects needed to meet FIFA's demands, specially of the federal government of Brazil, which included: reinforcement

\footnotetext{
4 "Ethnic cleansing can be understood as the expulsion of a population from a territory" (Bel-Fialkoff, 1993).
} 
of urban mobility, development or improvement of basic infrastructures (sanitation, water distribution, access, among others) and support facilities (accommodation and food, tourist agencies, leisure, shopping and entertainment, etc.) by football stadiums, among others. Consequently, city managers sought to design a new territory for tourists and the resident population, while highlighting the long-term benefits for the city, the state and the country.

Figure 1

\section{PHOTO A VILA AUTÓDROMO (RJ) AS AN EXAMPLE OF THE BARRING WALL, PHOTO B DUCT WALL AND PHOTO C BETWEEN WALLS, SEPARATING TWO DISTRICTS IN SÃO PAULO}
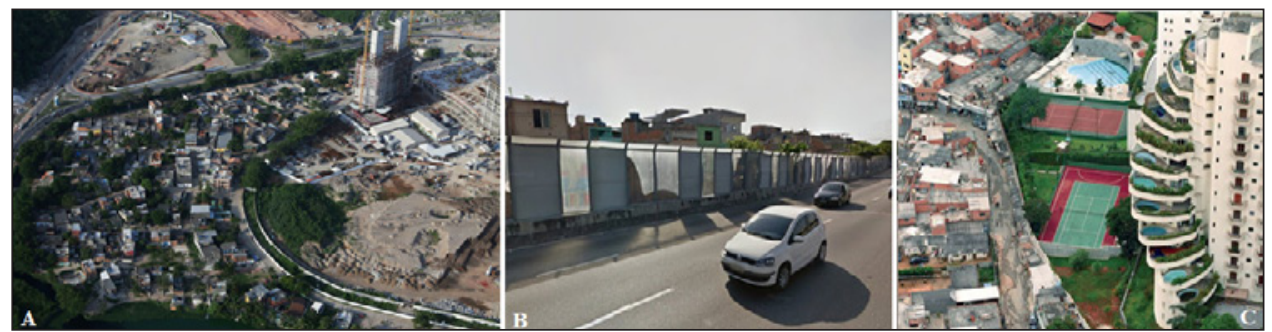

Sources: Mário Tama/ Getty Images (Foto A); site valeemfoco.pt (Foto C); Gohn, 2010 (Foto B)

Hall (2006, quoted by Maiello and Pasquinelli, 2015) states that the bidders of sports mega events argue that such events will have direct benefits, such as attracting capital, tourist flows and the development of urban infrastructure.

However, in the case of Rio de Janeiro, among all of the territorial-urban planning initiatives and the development of the necessary infrastructures, the process that remained was the deterritorialisation of the resident population in the places of tourist and sports interest, not only by removing large crowds from their neighbourhoods, but also the loss of their territories, since a new community entity had to be built. So the poorest communities living in the spaces needed for movement and/or the development of the desired infrastructures were removed from their original environment, which resulted in the loss of community/cultural identity, always "backed" by the laws in force and political interest (e.g. Transcarioca in Rio de Janeiro - Figure 2).

Burocco (2014) and Ramsey (2013) underscore that the deterritorialisation of - mostly poor - communities was noted in World Cups before Brazil. In South Africa, dissatisfaction with the 2010 World Cup brought to light the discontent of the poorer population toward the forced evictions, which were intended to mask the social reality in important parts of the main cities and made poverty invisible to tourists' eyes. According to the author, in Cape Town, Blikkiesdorp more precisely, residents said "that they were expelled from their old homes and had been taken there against their will, and they blamed the World Cup. By the road linking Cape Town airport to the city centre, residents were transferred to create the illusion of poverty-free South-African cities for football fans flying in from all around" (Burocco, 2014, p.68). 


\section{Figure 2 \\ LAYOUT OF THE TRANSCARIOCA COACH LINE}

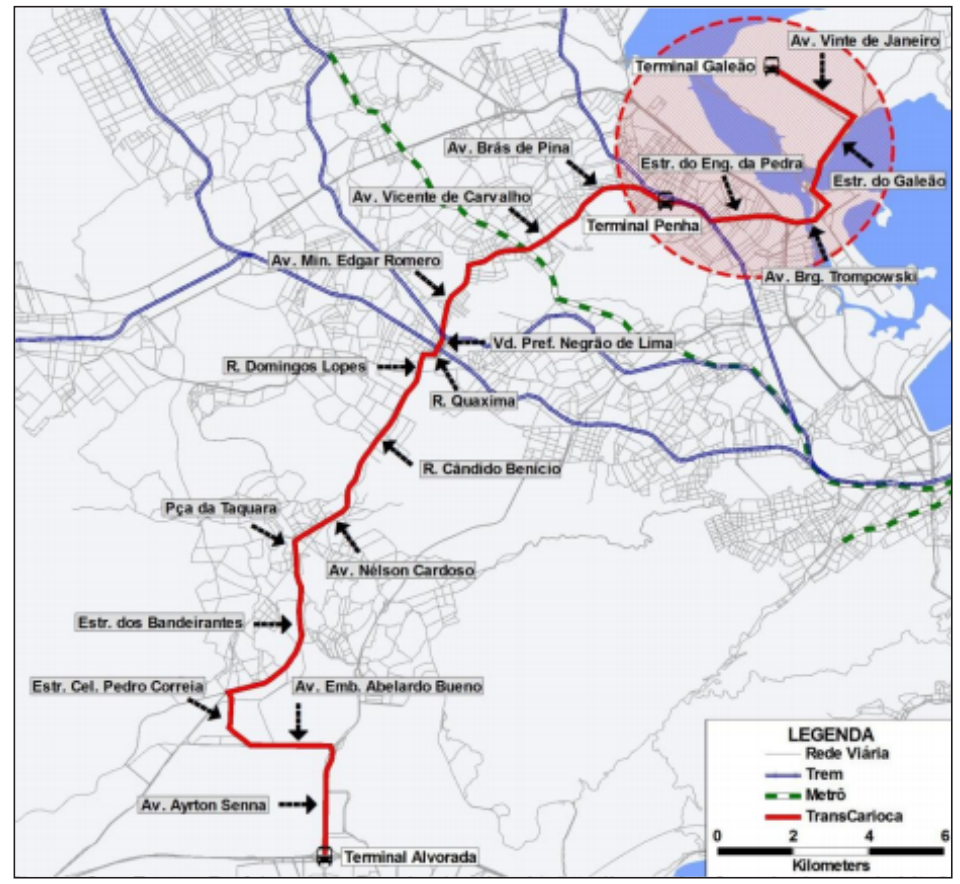

Source: Rio de Janeiro City Hall in http://www.plataformabndes.org.br/site/index. $\mathrm{php} /$ noticias/31-destaque/201-olimpiadas-anistia-internacional-apoia-fim-deremocoes-forcadas

Fernandes (2008: 426) says that:

"deterritorialisation processes, according to Haesbaert (2004), lead to loss of spatial reference (but not loss of space) and a process of involuntary uprooting, loss of autonomy and of freedom in the symbolic and functional appropriation of the geographical space, and, consequently, social and psychological crisis with identity and economic statement mismatch".

In the process of preparing host cities, non-governmental organisations like the UN and Amnesty International observed and produced documents presenting social outlooks on the impact caused by the activities of territorial adjustment. In 2009 the UN Special Rapporteur on adequate housing, Raquel Rolnik, addressed the UN Human Rights Council with some concerns and an analysis of sports mega events, expressing concerns about the right to housing and experiences of forced eviction. According to the rapporteur,

"in mega events the exercise of the right to adequate housing is not clear. Past experience has shown that rehabilitation projects adopted for games often result in the general breach 
of human rights, particularly the right to adequate housing. (...) The most disadvantaged and vulnerable parts of society, like low-income population, ethnic minorities, immigrants, the elderly, disabled people and marginalised groups (e.g. street vendors and sex workers) are the ones who suffer the most from such activities".

She highlights further:

\begin{abstract}
"the importance given to creating a new international image of the city, as part of getting ready for the games generally entails eliminating displays of poverty and underdevelopment, through redevelopment projects which prioritise urban embellishment over the needs of local inhabitants. Since public authorities use the organisation of mega events as catalyst of urban regeneration, inhabitants in those areas may have to face massive displacement, forced evictions and demolition of their homes".
\end{abstract}

Consequently, preparing tourist space for the interaction between tourists and residents often involves gentrification and deterritorialisation, but Deleuze e Guattari (1972 apud Ramos and Haesbaert, 2004: 29) find that "all deterritorialisation processes are bound by a dynamics of reterritorialisation". That is to say, observing the dynamics of territorial organisation for adjusting to the mega event's needs, it is seen displacement is almost always linked to compensation mechanisms, like rehousing in neighbourhoods built by the political power, through programmes granting access to adequate housing, or compensation evaluated on the basis of specific criteria.

\title{
3. THE RESEARCH: METHODOLOGICAL CHARACTERISTICS
}

Qualitative studies have become increasingly popular in different fields of knowledge, addressing emerging topics, like the subjectivity of social space, among others studied through exploratory research (Mozzato \& Grzybovski, 2011 and Shah \& Corley, 2006).

Methodologically speaking, the present research faced limitations due to its characteristics, its qualitative and exploratory nature. It is regarded as exploratory, as it addresses the territorial dynamics of sport events tourism. Also because the research is based on data of the official bodies of Brazil and the host cities of the World Cup, media, which provided relevant information for the composition and development of the paper's main argument (Selltiz et al., 1974). It is also qualitative, because there is already sufficient and updated information on the 2014 FIFA World Cup for expanding the understanding of the relevant variables for the studied cases, which cannot be quantified.

Considering the characteristics of the research, bibliographic and documentary research and case studies were established as data collecting tools. Therefore, the data and information was collected between January 2011 and August 2014 from the periodicals Jornal do Brasil (Globo), Veja magazine and O Globo newspaper, in addition to other magazines, newspapers and news websites (Table 2).

In addition to the researched sources in Table 1, we also chose to use as source the UN report on the right to housing (2010) and the Campaign by Amnesty International (2013/2014). 
Table 2

MEDIA RESEARCHED: ADDITIONAL INFORMATION

\begin{tabular}{|c|c|c|c|}
\hline Category & Medium & Headlines & $\begin{array}{c}\text { Date of } \\
\text { publication }\end{array}$ \\
\hline \multirow{3}{*}{ Deterritorialisation } & O Globo & $\begin{array}{l}\text { PM detém } 25 \text { ativistas da Aldeia Maracanã } \\
\text { (Military Police arrest } 25 \text { activists in the } \\
\text { Maracanã Village) }\end{array}$ & $16 / 12 / 2013$ \\
\hline & Article & $\begin{array}{l}\text { O processo de branqueamento do território } \\
\text { da pequena África: Os movimentos de } \\
\text { resistência ao projeto Porto Maravilha } \\
\text { (The process of whitening "small Africa": } \\
\text { resistance to the Porto Maravilha project) }\end{array}$ & 2014 \\
\hline & $\begin{array}{l}\text { Website of } \\
\text { the GGN } \\
\text { newspaper }\end{array}$ & $\frac{\text { Tropa de Choque cerca Aldeia Maracanã }}{\text { (Riot Police surround Maracanã Village) }}$ & $24 / 01 / 2013$ \\
\hline \multirow{2}{*}{ Gentrification } & $\begin{array}{c}\text { CBN } \\
\text { (Globo) }\end{array}$ & $\begin{array}{l}\text { Especulação imobiliária faz moradores se } \\
\text { mudarem de favelas da Zona Sul do Rio } \\
\text { (Property speculation drives residents out of } \\
\text { slums south of the River) }\end{array}$ & $17 / 04 / 2014$ \\
\hline & Article & $\begin{array}{l}\text { Forjando os anéis a paisagem imobiliária } \\
\text { pré-Olímpica no Rio de Janeiro (Designing } \\
\text { the circles of the real estate landscape of Rio } \\
\text { de Janeiro before the Olympic Games) }\end{array}$ & Dec. 2013 \\
\hline \multirow{3}{*}{ Reterritorialisation } & $\begin{array}{l}\text { Jornal do } \\
\text { Brasil }\end{array}$ & $\begin{array}{l}\text { Aldeia Maracanã: índios removidos entram } \\
\text { para o programa Minha Casa, Minha Vida } \\
\text { (Maracanã Village: evicted Indians are } \\
\text { brought into the housing programme Minha } \\
\text { Casa, Minha Vida) }\end{array}$ & $16 / 06 / 2014$ \\
\hline & G1 website & $\begin{array}{l}\text { Remoção de famílias para obras da Copa e } \\
\text { das Olimpíadas gera polêmica (Displacement } \\
\text { of families due to World Cup and Olympic } \\
\text { Game projects gives rise to controversy) }\end{array}$ & $20 / 08 / 2011$ \\
\hline & $\begin{array}{c}247 \\
\text { Website }\end{array}$ & $\begin{array}{c}\text { A história das remoções no Rio de Janeiro } \\
\text { (The story of displacements in Rio de } \\
\text { Janeiro) }\end{array}$ & $24 / 04 / 2014$ \\
\hline
\end{tabular}

Source: By the author, 2017.

Out of a universe of 12 host cities of the 2014 FIFA World Cup, we chose the host city of Rio de Janeiro, because of the larger amount of available data and information.

To analyse the information gathered, considering the research characteristics and the gathering of information, the content analysis method was chosen, as it is "a research 
technique that focuses on the word, which in practical terms and objectively makes it possible to infer from the content of a text and replicate the inferences in their social context" (Bauer, 2002 quoted by Cargnatto; Mutti, 2006: 682).

Consequently, to ensure a better and more precise analysis of the contents MAXQDA software was used; it analysed relevant study variables, like community and mega event, tourism and host city, social exclusion and gentrification, public goods and private goods, deterritorialisation and reterritorialisation, on the basis of the frequency of keywords for inference by identifying objectively the characteristics of the content/message analysed (Weber, 1985 and Bardin, 1977). The social nature of content analysis thus stands out as a technique that is based on the production of inferences from one content to its social context (Bauer e Gaskell, 2002).

Therefore, the choice of subject to be discussed is justified, as it answers some initial questions about territorial changes, i.e.: Are the necessary changes for adjusting the city to the size of the event or for encouraging private initiative opportunism? In the process of changing the territory is there a strategy for creating an artificial cultural/ tourist space $^{5}$ (movement, accessibility to services, housing, transport, etc.), to the detriment of requirements for holding events?

Section 4 includes a critical analysis of the 2014 FIFA World Cup mega event, based on the preliminary questions, the researched sources and the methodology used.

\section{RESEARCH RESULTS}

Building the tourist image of Rio de Janeiro: the paradox between a positive image and structural and political issues.

In the process of territorial and urban redevelopment conducted by the managers of the city hosting the 2014 FIFA World Cup, Rio de Janeiro, the balance between economic and social-environmental forces is unequal. This perception is drawn from Michel De Certeau's (1998) understanding of cities. He clarifies that the city is perceived from antagonistic points of view: that of the dominant class and of the users. The former, founded on power, sees the city only as an object that fosters forms of control - tables, letters, statistics; the latter, without specific knowledge about the city, lives in and relates with the city. It is the social class that is entitled to a culture of immediate satisfaction, as observed by Galbraith (1992). Physical and abstract structures present emotional/intellectual meanings and values for users. The city is for them the real thing, a collective work produced by culture.

Michel De Certeau (1998: 172-173) states that

"the city brought by utopian and urban discourse is defined by a possible triple operation: 1 . The production of own space...; 2. Establishing non-time or a synchronic system...; 3. Finally, the development of a universal subject and anonymous, which is the city itself: as the political model, little by little one can award to Hobbes's state all functions and attributes until then

5 In this paper, the following definitions by Boullón (1997) are used: Cultural Space - The part of the Earth's crust whose original shape changed under human activity. (...) it is the result of work done by people, for preparing the earth for their needs. Tourist space - It is the result of the presence and territorial distribution of tourist attractions (...). 
disseminated and given to several real subjects, groups, associations, individuals. 'The city', like a proper name, offers the possibility of designing and constructing space from a finite number of stable, individual and articulated properties. In such place, organised according to 'speculative' and classification operations, management is combined with elimination".

Frémont (1980) thus highlights that space built on non-participatory bases facilitates ongoing emptying of space and its intrinsic values through transfer, reducing such space to the sum of places governed by bodies and appropriation mechanisms, of social limitation and reproduction (Frémont, 1980, p.242). Consequently, human beings become strangers to themselves and the space they live in. The author finds that such alien spaces are produced in two illusionary ways: nostalgia of the past and dogmatic redevelopment, which interfere in the process of transfer, replacing present realities with idealised landscapes and places. Contrary to the alienation of space, Frémont (1980) emphasises the need of understanding space in the present reality, as a space with life, built and represented by social actors in that space.

Therefore, the process of territorial dispute sought to adjust the space for the World Cup's infrastructures, with the communities residing in the areas of interest on the one side and Government and private initiative on the other.

Large interventions in Rio de Janeiro were carried out through structural projects, particularly in the areas of mobility, public security and sports facilities, which included: a) urban mobility: development of an integrated BRT, BRS and VLT transport system, the underground line 4 and new lanes for cars by Barra da Tijuca; b) Public security: development of UPPs - Peace Sustaining Police Units - in the city centre and southern areas; c) Sports facilities: refurbishment of the Maracanã stadium, construction of the Olympic park and adjacent structures. The aim was to reinforce existing centralities, and revive port areas and the city centre.

To implement the necessary changes to the territory of the city of Rio de Janeiro, the political power disregarded the territoriality of the communities involved, and appointed task-forces for identifying, registering and compensating families who agreed with the expropriation terms and conditions.

Consequently, based on the preliminary information on the process of change of the urban space of Rio de Janeiro, data was collected from the Brazilian mass media, using the key-words football, displacement, deterritorialisation, gentrification, speculation and tourism. The publications described in the research methodology showed the following activities of the city's government and the government of the state of Rio de Janeiro:

a) Deterritorialisation and reterritorialisation: In 2011, as reported by G1 (Globo Communications Company), the secretary of housing of the city of Rio de Janeiro, Jorge Bittar, showed that the displacements had not been forced, as the municipal housing policy provided for them, and that the city would take the opportunity to reduce the housing deficit which, the secretary mentioned, amounted at the time to 220 thousand units.

Information from the Municipal Secretary for Housing pointed to almost one thousand families of the community of Vila Recreio II, on the west side of the city, who had been displaced for the construction of the trans-west motorway (Figure 3), 
totalling around 12,812 families resettled, 1,965 compensated, 1,374 receiving purchase support and 5,473 families transferred and awarded social rents from 2009 to 2012.

Figure 3

\section{MAP OF THE BRT PUBLIC TRANSPORT SYSTEM OF RIO DE JANEIRO}

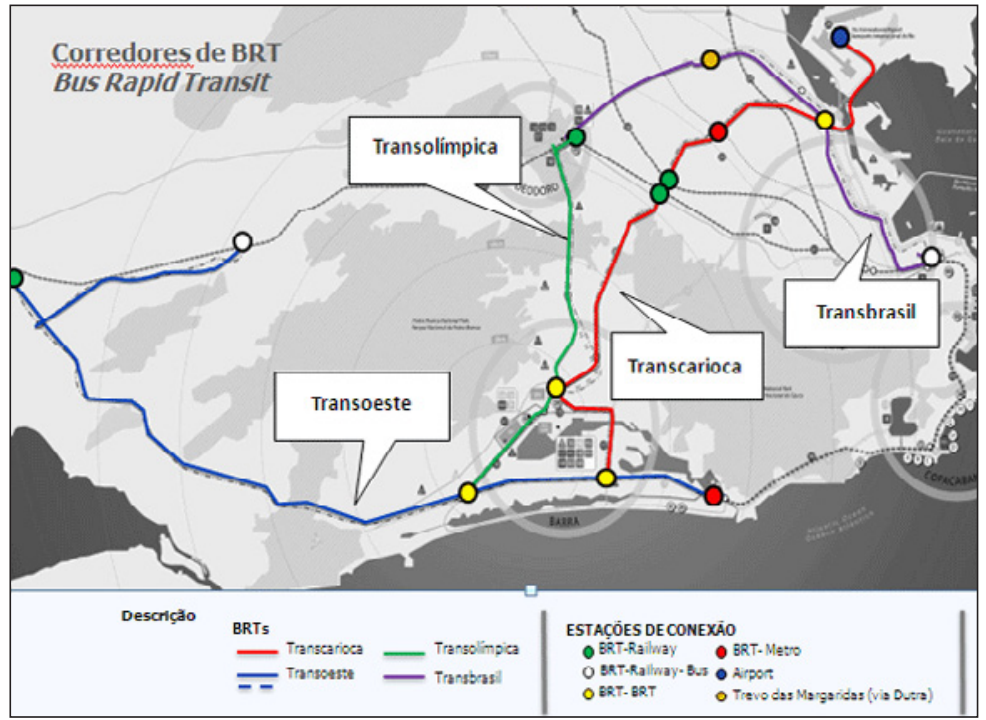

Source: Rio de Janeiro city hall, 2011.

Haesbaert (2014) explained that deterritorialisation and reterritorialisation are processes that are sometimes misunderstood and wrongly contextualised, as in some cases in Rio de Janeiro, residents were kept in an ongoing and/or continuous experience between real space and the tourist space (Boullón, 2002), thus characterising multiple territory as it is perceived by Haesbaert (2014).

b) Social exclusion and gentrification: the loss of community identity is one of the characteristics of gentrification, which initially is followed by the process of deterritorialisation and then by reterritorialisation (Haesbaert, 2014); when faced with the new reality of expropriated families and others who remained in place, we see the disconnection between community dynamics and the tools used to convince people about the new meaning of the space that will be adjusted to new standards.

By 2015 more than 24 thousand families had been evicted and their homes had been pulled down to give way to new structures (Figure 4).

Vila Autódromo was a landmark in the city of Rio de Janeiro. After the Football Word Cup it was subject to property speculation with the support of municipal public power. A high-end mega condominium in Barra da Tijuca was projected and implemented, composed of 31 buildings, 17 floors each, over 800 thousand $\mathrm{m} 2$, under the PPP programme signed by the mayor of Rio and a consortium of building companies (Carta Maior, 2015). 
According to Siqueira (2014: 393) the present view on gentrification provides a broader scope of the process which "includes a variety of uses, agents and forms of spatial intervention". In the case of Rio de Janeiro, gentrification, as Chernoff highlighted (2010), was commercial and tourist (Gotham, 2005).

\section{Figure 4 \\ ILHA PURA CONDOMINIUM (TERRITORY OF VILA AUTÓDROMO)}

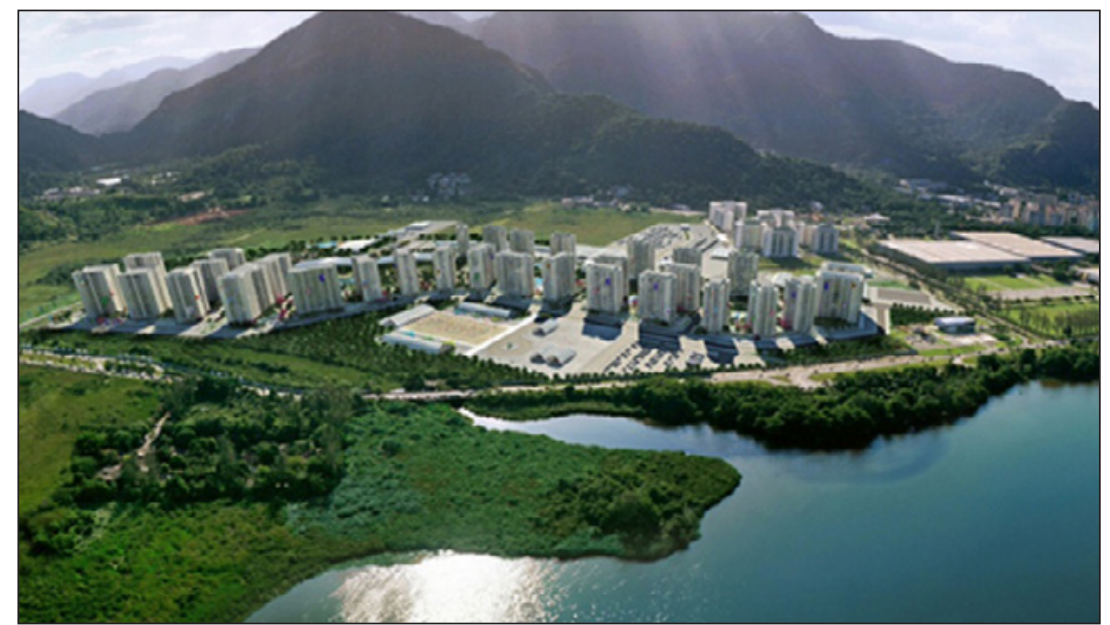

Photo: Carta Maior, 2015.

c) Community and mega-event: Studies before and after the 2014 FIFA World Cup mega-event (Pacheco, 2015; Gaffney, 2016; Magalhães, 2013; Gaffney 2010) establish three different stages in the perception of residents. The first features expectation, which is founded on the understanding that there will be a legacy and that the population will be included in the inheritance process of the buildings. The second stage reflects influential factors, presenting a new reality, i.e. that the expectation is not compatible with fulfilment thereof. And the third after the event involves the realisation that the expected reality was not fulfilled. However, when we look at the environment with the tourist flows, the perceptions of the Football Word Cup mega event change.

The demonstrations of resistance to the 2014 FIFA World Cup showed concern, and some rejection, about the changes in the city of Rio de Janeiro, and other intrinsic factors of the process, e.g. political. Pacheco (2015) states that in Rio de Janeiro the population is generally conformed, in spite of some outbreaks of resistance against tourists and the football mega-event, arising from several pre-event factors that influenced motivation, like the euphoria of hosting the World $\mathrm{Cup}^{\mathrm{TM}}$ or holding the event itself. After the event, the perception is established, taking into account the influencing factors. However, the inhabitant of Rio de Janeiro, who has become accustomed to receiving tourists during the year, remains conformed (Figure 5), except in the communities impacted by gentrification processes. 
It is observed, considering Pacheco's findings (2015: 46) on a "possible resistance of the population to tourists due to dissatisfaction with hosting the 2014 World Cup, that most disagree in the three phases surveyed."

\section{Figure 5 \\ CHART REPRESENTING THE RESISTANCE \\ OF THE POPULATION TO TOURISTS}

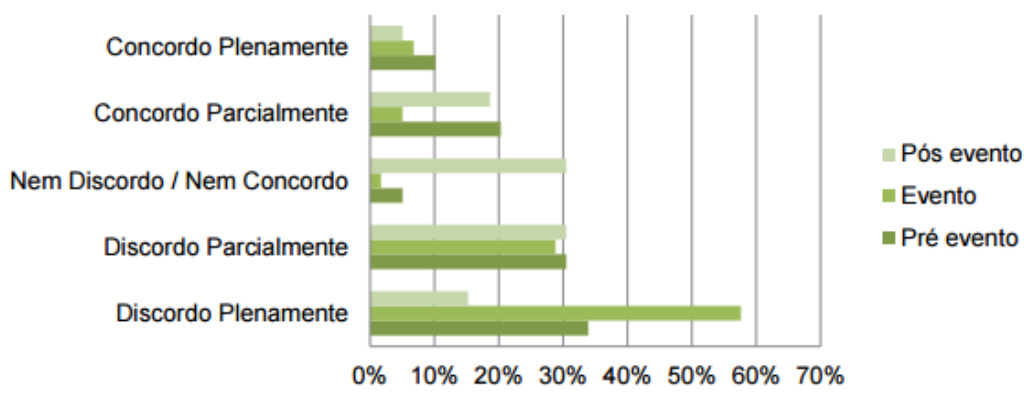

Source: Pacheco, 2015.

d) Tourism and Rio de Janeiro: in spite of the new social-economic dynamics enforced by the 2014 FIFA World Cup, which, as mentioned before, drove change into the territory of the host cities and triggered all sorts of feelings in the resident population, from pride to total rejection, it was also a facilitator of growing tourist flows. According to Riotur - the tourism company owned by the city of Rio de Janeiro (G1, 2014) - 886 thousand tourists, 441 thousand foreigners and 445 thousand Brazilians, came to Rio de Janeiro during the FIFA World Cup, and left in the city - total spending - approximately US\$1,330,000,000 during the event. Accommodation was among the sectors that benefited the most, having recorded $97.8 \%$ occupation. The intense tourist flow was felt in areas that had been established in the tourist plans for the mega-event, as the data provided by 31 information points (fixed and temporary) point out, with over 34,400 services delivered from 02 to 15 June (Riotur, 2014). The geographical distribution of the tourist information points prioritised points of arrival, tourist corridors, tourist attractions and districts where most of the hotels were concentrated, for example the Tom Jobim International Airport (approximately 5,000 visits), underground (4,690), Santos Dumont International Airport $(4,900)$, Maracanã $(4,200)$, Ipanema $(2,500$ and BRT $(2,240)$ (Riotur, 2014).

This context of elitism of space and limiting the movement of visitors within certain areas of the city's territory, specially through the access to transport and public services, in the view of Gaffney (2015), emerged from the transformation process which responded in scale and speed to the interests of sub-contractors, sponsors and governments, restructuring the image of the city.

Rio de Janeiro suffered some impacts which it had not wished for, i.e. the transformation of citizens' space into an area for tourists and sports. Such reality that emerged from capital needs was exposed by the UN Human Development Council, which addressed 
a recommendation to the Brazilian government in 2012; it stated that Brazil should "Guarantee that the urban restructuring before the 2014 World Cup and the 2016 Olympics is suitably regulated to avoid displacements and forced eviction and endeavour to ensure that future events bring lasting benefits for the poor and more marginalised fraction of city dwellers" (ONU, 2012).

On the other hand, Brazilian mass media devised, with government funding - through advertising -, a positive image of the 2014 FIFA World Cup mega event, spreading the news that a legacy that would be accessible to the people was being built, guided by the political agenda of the presidential elections that would be held in 2014 .

Consequently, from January 2010 to June 2013 (the month of the first demonstration against Dilma's government), the headlines of the main national newspapers and magazines (Figure 6) tried to attribute to the mega event the image of provider of an advantage that no other agent or medium could grant in the short term.

\section{Figure 6 \\ CLOUD OF WORDS THAT APPEARED MORE FREQUENTLY IN NEWSPAPER AND MAGAZINE ARTICLES FROM 2010 TO JUNE 2013}

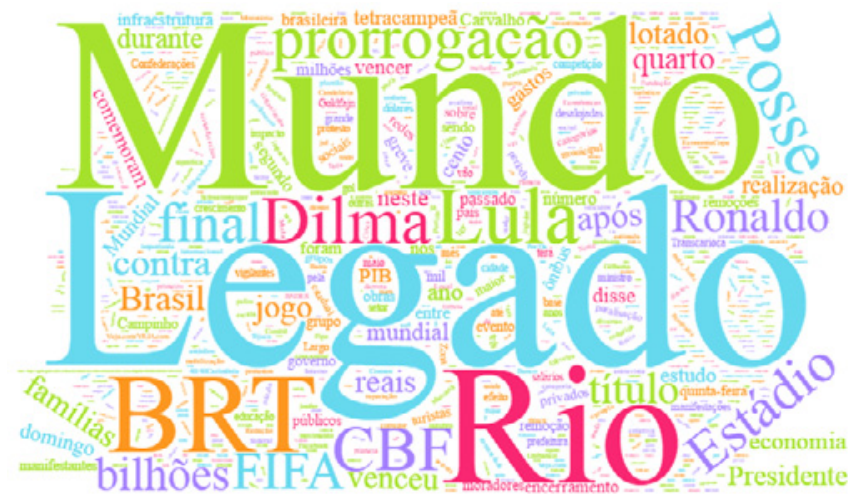

Source: Created by the author (2017) with the magazines and newspapers in Table 01 and issues of O Globo, Veja magazine and Jornal do Brasil.

However, after several events that characterised an agitated pre-event period, such as delays in structural and sports infrastructure projects, corruption allegations, the displacement of poorer communities, redesign of areas to respond to the needs of the mega event and tourism, among others, besides the political downturn working against president Dilma Rouseff in 2014, the media adopted a different approach to the facts, stating that "there will be no legacy" regarding the heritage that the city of Rio de Janeiro would be left by the 2014 FIFA World Cup.

Analysing the periodicals Jornal do Brasil (Chart 01), O Globo (Chart 02) and Veja magazine (Chart 03), one sees the contents in favour of the mega event turn into arguments against. Initially, they sought to create and reinforce a positive image of the valorisation of the territory. Later, there was a political shift in news content. 
So, for greater precision and meaning of inferences, the following analysis categories and key-words were established: Deterritorialisation (displacement, eviction and reintegration of possession), Reterritorialisation (settlement and housing policy) and Gentrification (space elitism, tourism and property speculation). These categories were generated from empirical material analysed and are not deductive.

Therefore, 132 units of meaning were taken from news reports in the Jornal do Brasil. The logic of the news structure was analysed, the major factor of the period analysed being the 2014 FIFA World Cup. Observing the key-words and the content published, between January 2010 and June 2013 Jornal do Brasil focused on news that highlighted conflicts and resistance to the mega event, specially concerning the deterritorialisation process (49\%) characterised in the case of Aldeia Maracanã. From July 2013 to August 2014, the periodical addressed issues concerning reterritorialisation (47\%), particularly in cases like the housing programme Minha Casa, Minha Vida. In parallel with the two other topics, the periodical addressed the gentrification topic related to the infrastructure projects and the new meaning given to urban space in Rio de Janeiro.

\section{Chart 01}

\section{TOPICS ADDRESSED IN THE ARTICLES OF THE JORNAL DO BRASIL}

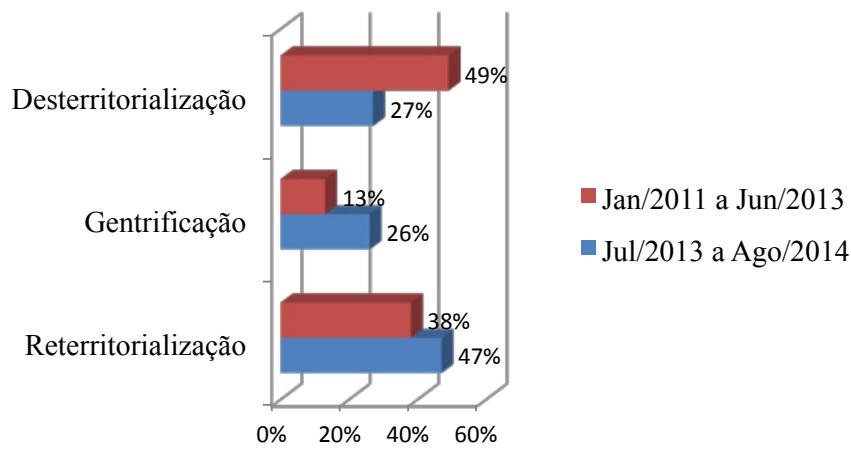

Source: Written by the authors, 2017.

In the periodical O Globo, 43 units of meaning were quantified based on the key-words and the direct influence of the political context on the choice of news topics was clear, whereas from the demonstrations in June 2013 the headlines shifted their focus. In other words, from January 2010 to June 2013 the articles emphasised the benefits (reurbanisation and resettlements $-56 \%$ ) for the population of Rio de Janeiro and other host cities. From July 2013 to August 2014 they highlighted the negative aspects, fundamentally related to the impacts of the political environment, incomplete and delayed infrastructure projects, displacements and violence $(52 \%)$.

Furthermore, in O Globo newspaper and Veja magazine, 36 units of meaning were identified, with similar motivation. From January 2010 to June 2013 the articles adopted a positive approach to the mega event, occasionally addressing the issue of governments' fault in the delays in the works and suspicion of acts of corruption. They focused on the topics 
of settlement and the housing programme Minha Casa, Minha Vida (reterritorialisation - 46\%). However, there was a shift in the focus from July 2013 against the backdrop of Brazilian politics, which emerged from the more negative topics linked with the political image of managers, e.g. the displacements (deterritorialisation - 52\%), suspicion of corruption and public demonstrations with a political dimension. To support the above, 32 units of meaning were recorded.

\section{Chart 02}

\section{TOPICS ADDRESSED IN THE ARTICLES OF THE O GLOBO}

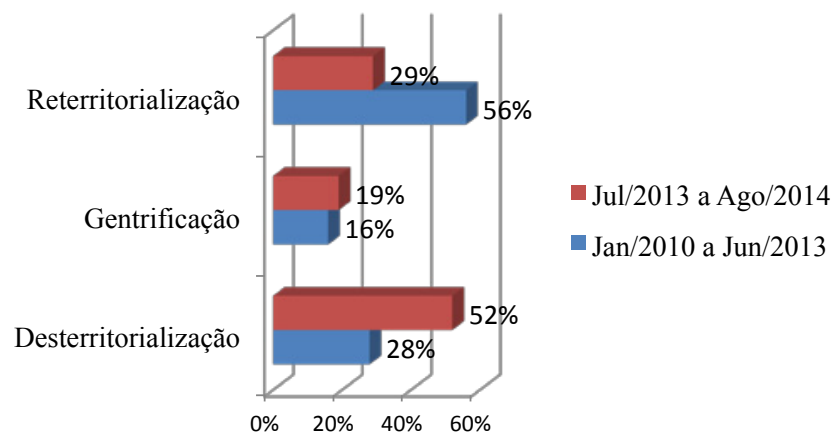

Source: Written by the authors, 2017.

\section{Chart 03}

TOPICS ADDRESSED IN THE ARTICLES OF THE MAGAZINE VEJA

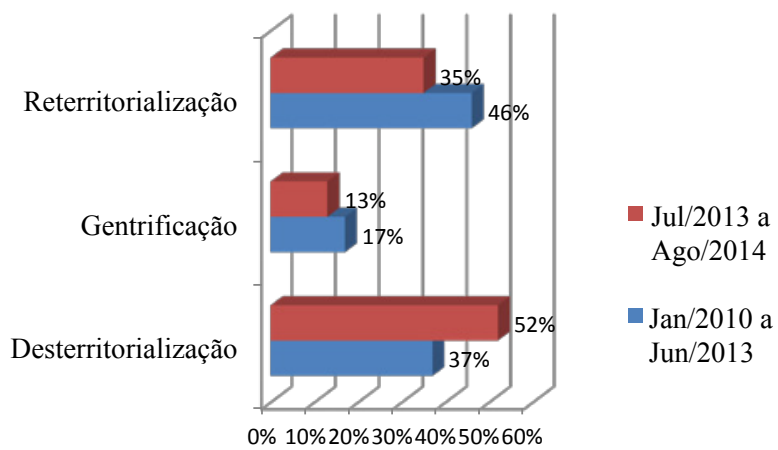

Source: Written by the authors, 2017.

Concerning the gentrification process, the communities living in the corridors of access to sports infrastructures, like football stadiums and tourist spaces, were listed as living in places of interest for the event. Consequently, they were displaced and expropriated, and the value of the buildings or properties rocketed as a result of property speculation. 


\section{CONCLUSIONS}

In the present research one understands that one of the main implications of urban intervention in Rio de Janeiro was the attraction of a wealthier social class than the one originally living on the territory, which settled in thanks to the conversion, transformation and development of new buildings that responded to their needs, and that fundamentally aligned the landscape with the image intended by the political power and the real estate capital of Rio de Janeiro. This perception is upheld by Bataller (2000) and Slater's (2003) views on gentrification. Linked with this process, others like deterritorialisation and reterritorialisation help to understand the new meaning of space, replacing the community context with a more useful one from a social and tourist perspective.

The publications researched began by emphasising the positive events linked with the 2014 FIFA World Cup, specially from January 2010 to June 2013. The more negative impacts were printed on the back pages of the periodicals (Figure 6), with the aim of constructing a friendlier narrative around the idea of a legacy for sports, well-being and infrastructure.

The inferences above are the product of the answers to the initial questions. When asked whether the necessary changes envisaged adjusting the city to the size of the event or supporting the opportunism of private initiative, we find that it was a combination of interests. However, to respond to several goals of the organising committees of the mega event in view of meeting infrastructural needs and that of speculative real estate capital linked to subcontractors and public power, which widened the social and economic gap in the city of Rio de Janeiro.

Notwithstanding the variety of interests, Brazilian press, in particular the periodicals researched hereunder, disseminated the discourse of a positive image of the country and the 2014 FIFA World Cup, of the Cup's legacy. It went to great lengths to highlight the advantages of hosting a mega-event, underlining the infrastructural, economic and social elements. However, the reality of the preparation of the urban space in the host city of Rio de Janeiro appeared little by little, and increasingly made the headlines of the press. The facts explained and described in Figure 06 and Charts 01, 02 and 03 tell the story of territory that the city's poorest population lost - particularly those who possessed areas of interest - for the organisers and real estate speculators (Figure 02, 03 and 04).

The displacement of the deprived communities and/or the ones belonging to the social minorities of their "lands" of origin breached the constitutional principle of the social function of property, which is the principle of the economic and financial order (Article 170, III, CRFB / 1988) and reinforced the terms of the constitutional provisions on urban policy (Articles 182 and 183, CRFB / 1988).

The projects of ennobling/gentrifying urban areas and the displacement of communities gave the World Cup host cities a sense of security and beauty. In line with the statement above, Ley (1981, mentioned by Furtado, 2014) said that the market that harms the poorer fractions of society due to lack of investment in some areas of the city penalises that social group through excessive investment.

Consequently, the construction of the tourist-sport space was sustained by governments' subjective assessment of constitutional provisions, from which they 
inferred that property right cannot be founded solely on private grounds, governed by rules on the supremacy of the personal sphere over the collective sphere. In this case government understanding was that the city represents collective interests, which override the individuality of a community, i.e. the wishes and interests of a population group cannot have supremacy over the needs of a city, in the case of infrastructure projects for the 2014 World Cup, which thus justified the displacement of residents from the areas of tourist-sports interest.

Consequently, there was the need to answer another urgent question, which inquired about the real goal underlying the transformation of the territory. The research findings point to an understanding that PPPs for urban and social redevelopment, registered by the Brazilian press, revealed the overlapping of economic forces over social ones, taming public will - as underlined in the reports in Table 01 .

The editorial shift in the statement of a legacy that the World Football Cup mega event would leave, connected to Brazilian love for football, is more assertive from June 2013, during the large public protest of political nature directed to the presidency of the republic, which echoed throughout other moments until the start of the competition. National newspapers and magazines started to emphasise the weaknesses of preparing the space for the mega event and tourism, which reflects the political influence on the periodicals (Charts 01,02 and 03).

We must remember that, according to Santos (2014: 452), cities present themselves with the "nature of a multi-product associated with overlapping layers of space with multiple historical backgrounds, which make up the urban structure and are used as tourist products through the activities and intervention of multiple stakeholders". However, in the case of the mega event in question, Brazilian tourist identity from 2007 to 2014 was reflected in football, and was also connected with carnival /samba due to the marketing strategies of the Brazilian tourist product and the infrastructures that were created and recreated. Such tourist products addressed the organisational objectives and occasionally excluded other identity features of tourist-cultural importance.

To conclude the reasoning, it is understood that the process of preparing tourist and sports spaces in Rio de Janeiro for the 2014 FIFA World Cup was founded on deterritorialisation and reterritorialisation processes - which, in the eyes of Haesbaert (2014), generate multiple territories in the individual and the communities - , and on gentrification, raising the economic value of spaces and infrastructure, to achieve a new territorial dynamic and the return on the capital invested.

\section{REFERENCES}

AMNESTY INTERNATIONAL (2014): Campaign against repression of protests during the World Cup. Accessed on 15/06/14 at https://anistia.org.br/imprensa/press-release/ anistia-internacional-lanca-campanha-mundial-contra-repressao-aos-protestosdurante-copa-mundo-brasil/

ARTICULAÇÃO NACIONAL DOS COMITÊS POPULARES DA COPA (2012): Dossiê da Articulação Nacional dos Comitês Populares da Copa: Megaeventos e Violações de Direitos Humanos no Brasil. 
AUGUSTO, L. (2014): Comunicação e Turismo: relações públicas, dialogismo e imagem nos media digitais. Tese de Doutoramento. Faculdade de Letras, Universidade de Coimbra.

BARDIN, L. (1977): Análise de conteúdo. Lisboa: Edições 70.

BATALLER, M.A. (2000): “O Estudo da Gentrificação”. Biblio3W. Revista Bibliográfica de Geografía y Ciencias Sociales, $\mathrm{n}^{\circ} 228$.

BAUER, M.W. and GASKELL, G. (2002): Pesquisa qualitativa com texto, imagem e som: um manual prático. Petrópolis: Vozes.

BELL-FIALKOFF, A. (1993): A brief history of ethnic cleansing Foreign Affairs. ABI/ INFORM Global.

BOULlÓN, R.C. (1997): Planificación Del Espacio Turístico. $3^{\mathrm{a}}$ Ed. México, Trillas.

BOULLÓN, R.C. (2002); Planejamento do espaço turístico. Bauru, SP Edusc.

BUROCCO, L. (2014): “África do Sul: Copa para quem e para quê? Um olhar sobre os legados dos mundiais de futebol no Brasil, África do Sul e Alemanha”. In: Marilene de Paula, Dawid Danilo Bartelt (Org.), Rio de Janeiro: Fundação Heinrich Böll.

CAREGNATO, R. and MUTTI, R. (2006). "Pesquisa qualitativa: análise de discurso versus análise de conteúdo”. Contexto Enferm, Florianópolis Out-Dez; 15 (4), pp. 679-84.

CERTEAU, M. (1998): A Invenção do Cotidiano: Artes de Fazer. $3^{\mathrm{a}}$ ed. Vozes, Petrópolis.

CHERNOFF, M. (2010): Social displacement in a renovating neighborhood's commercial district. In: Brown-Saracino, J. (Org). The gentrification debates: a reader. Nova York, Routledge.

CLIFT, J. (2010): "Price or Penalty". Finance \& Development. March, pp.6-7

CONSTITUIÇÃO DA REPÚBLICA FEDERATIVA DO BRASIL (1988) (Constitution of the Federal Republic of Brazil).

FERNANDES, J. (2008): “A desterritorialização como factor de insegurança e crise social no mundo contemporâneo", in I Jornadas Internacionais de Estudos sobre Questões Sociais. AGIR - Associação para a Investigação e Desenvolvimento Sócio-Cultural. Póvoa de Varzim (pp.423-447).

FRÉMONT, A. (1980): A região, espaço vivido. Portugal, Coimbra: Livraria Almedina.

FURTADO, C.R. (2014): "Intervenção do Estado e (Re)estruturação Urbana. Um Estudo sobre Gentrificação”. Cad. Metrop., São Paulo, vol. 6 (32), pp. 341-363.

GAFFNEY, C. (2010): "Mega-events and socio-spatial dynamics in Rio de Janeiro, 19192016". Journal of Latin American Geography, vol. 1 (9), pp. 07-29.

GAFFNEY, C. (2014): “A World Cup for Whom? The impact of the 2014 World Cup on Brazilian football stadiums and cultures". In: Gaffney, C. and Fontes, P. The Country of Football: Politics, Popular Culture, and the Beautiful Game in Brazil.

GAFFNEY, C. (2015): "Virando o jogo: The Challenges and Possibilities for Social Mobilization in Brazilian Football”. Jornal Sports and Social Issues, vol. 39 (2), pp. 155-174.

GAFFNEY, C. (2016): “An Anatomy of Resistance: The Popular Committees of the FIFA World Cup in Brazil. In: Dart, J and Wagg, S. Sport, Protest and Globalisation. Springer.

GALBRAITH, J.K. (1992): La cultura de la satisfacción. Los impuestos, para qué? Quiénes son los beneficiarios? Barcelona, Ariel. 
GOHN, M.G. (2010): "Morumbi: o contraditório bairro-região de São Paulo". Caderno CRH, vol. 23 (59), pp. 267-281.

GOTHAM, K. (2005): “Tourism Gentrification: The Case of New Orleans Vieux Carré (French Quarter)". Urban Studies. Glasgow, vol. 42 (7), pp. 1099-1121

GRÜNEWALD, R. (2003): “Turismo e Etnicidade”. Porto Alegre, Horizontes Antropológicos, vol. 9 (20), pp. 141-159.

HAESBAERT, R. (2010): "Territórios, in-segurança e risco em tempos de contenção territorial”. In: Póvoa Neto, H., Ferreira, A. Vainer, C., Santos M. (Org.) A experiência migrante: entre deslocamentos e reconstruções. Rio de Janeiro: Garamond. pp. 537-557.

HAESBAERT, R. and RAMOS, T. (2004): "O mito da desterritorialização econômica". GEOgraphia, vol. 6 (12), pp. 25-48.

HAESBAERT, R. (2007): “Território e multiterritorialidade: um debate”. GEOgraphia, vol. 9 (17), pp. 19-46.

HARVEY, D. (2008): “The Right to the City". New Left Review, no 53, September-October.

JORNAL DO BRASIL. (2014): "Copa 2014 tem gastos públicos recordes, em benefício da iniciativa privada". Accessed on 12/09/2016. Available at http://www.jb.com.br/ pais/noticias/2014/01/31/copa-2014-tem-gastos-publicos-recordes-em-beneficio-dainiciativa-privada/

JORNAL DO BRASIL. (2012): “Copa do Mundo 2014 e Olimpíada 2016”. Accessed on 12/09/2016. Available at http://www.jb.com.br/sociedade-aberta/noticias/2012/07/01/ copa-do-mundo-2014-e-olimpiada-2016/

JORNAL DO BRASIL. (2014): "Grupos preparam Dia Internacional de Lutas contra a Copa do Mundo para quinta". Accessed on 13/09/2016. Available at http://www. jb.com.br/pais/noticias/2014/05/13/grupos-preparam-dia-internacional-de-lutas-contra-a-copa-do-mundo-para-quinta/

JORNAL DO BRASIL. (2013): "Mobilidade urbana na Copa 2014 pode ter sérios problemas". Accessed on 13/09/2016. Available at http://www.jb.com.br/rio/noticias/2013/08/18/mobilidade-urbana-na-copa-2014-pode-ter-serios-problemas/

JORNAL DO BRASIL. (2011): "Protesto reúne desalojados por obras da Copa 2014". Accessed on 15/09/2016. Available at http://www.jb.com.br/rio/noticias/2011/07/30/ protesto-reune-desalojados-por-obras-da-copa-2014/

JORNAL DO BRASIL. (2014): "Ministro vê legado da Copa em investimentos em comunicações". Accessed on 15/09/2016. Available on http://www.jb.com.br/cienciae-tecnologia/noticias/2014/05/27/ministro-ve-legado-da-copa-em-investimentos-emcomunicacoes/?from_rss=None

JORNAL DO BRASIL (2014): "FIFA anuncia legado com valores quatro vezes menores". Accessed on 17/09/2016. Available at http://www.jb.com.br/jb-na-copa/noticias/2014/06/18/fifa-anuncia-legado-com-valores-quatro-vezes-menores/

JORNAL O GLOBO. (2013): "Dia de protestos contra a Copa do Mundo". Accessed on 19/09/2016. Available at https://oglobo.globo.com/brasil/dia-de-protestos-contra-copado-mundo-12492838

JORNAL O GLOBO. (2011): "Rocinha terá obras de R\$ 756 milhões até 2014". Acervo Jornal $O$ Globo, Cadernos da Edição de 15 de novembro. 
JORNAL O GLOBO (2013): "Final: The 2014 FIFA". Acervo do Jornal O Globo, Cadernos da Edição de 7 de dezembro.

MACCANNELL, D. (1992): "The Locke case", in MacCannell Dean, Empty meeting grounds, London, Routledge.

MAGAlHÃES, L. G. (2013): Com a taça nas mãos: sociedade, Copa do Mundo e ditadura no Brasil e na Argentina. Tese de doutorado. Universidade Federal Fluminense.

MAIELLO, A. and PASQUINELLI, C. (2015): "Destruction or construction? A (counter) branding analysis of sport mega-events in Rio de Janeiro". Cities, vol. 48, pp. 116-124.

ONU (2010): Documento Análises, impressões críticas e recomendações a respeito da prática dos megaeventos nas cidades e seu impacto sobre o direito à moradia adequada. Tradução livre da ONG FASE.

ONU (2012): Recomendação do Conselho de DHs da ONU ao Brasil no âmbito da Revisão Periódica Universal - maio de 2012.

PAPPAS, N. (2014): "Hosting mega events: Londoners' support of the 2012 Olympics". Journal Of Hospitality and Tourism Management, vol. 21, pp.10-17.

PACHECO, T da S. (2015): Copa do Mundo FIFA 2014 ${ }^{T M}$ : Percepções dos residentes da cidade do Rio de Janeiro. Universidade Federal Fluminense.

POUTGNAT, P. and STREIFF, F.J. (1998): Teorias da Etnicidade seguido de grupos étnicos e suas fronteiras de Fredrik Barth. Traduzido por: Elcio Fernandes. São Paulo. Fundação Editora da UNESP.

RAMSEY, A. (2013): Social Issues of World Cup in Africa!, Duke University. Acessed on: 18/09/2016. Available at: https://sites.duke.edu/wcwp/world-cup-014/the-2010-southafricaworld-cup-highlights-politics-lessons-for-brazil/socialissues-of-world-cup-insouth-africa/

REVISTA VEJA. (2014): “O legado imaginário da Copa das Copas foi embora junto com os turistas. Ficou com os brasileiros a conta da Copa da Roubalheira". Accessed on 20/09/2016. Available at http://veja.abril.com.br/blog/augusto-nunes/o-legado-imaginario-da-copa-das-copas-foi-embora-junto-com-os-turistas-ficou-com-os-brasileirosa-conta-da-copa-da-roubalheira/

REVISTA VEJA. (2015): "FIFA vai investir US\$ 260 mi no Brasil como legado da Copa". Accessed on 20/09/2016. Available at http://veja.abril.com.br/esporte/fifa-vai-investirr-260-mi-no-brasil-como-legado-da-copa/

REVISTA VEJA. (2013): "Governo age para evitar desgaste com os protestos na Copa". Accessed on 20/09/2016. Available at http://veja.abril.com.br/blog/reinaldo/governoage-para-evitar-desgaste-com-protestos-na-copa/

REVISTA VEJA (2012): “Como a Copa vai obrigar o país a enfrentar seus problemas". Accessed on 21/09/2016. Available at http://veja.abril.com.br/esporte/como-a-copavai-obrigar-o-pais-a-enfrentar-seus-problemas/

RIBEIRO, D. (1995): O Povo Brasileiro: A formação e o sentido do Brasil. São Paulo: Companhia das Letras.

RIBEIRO, L.P. (2014): “O Processo de Branqueamento do Território da Pequena África: os movimentos de resistência ao projeto Porto Maravilha”. Anais do I Congresso Brasileiro de Geografia Política, Geopolítica e Gestão do Território. Rio de Janeiro. REBRAGEO, pp. 1270-1277. 
RODRIGUES, A.B. (1999): Turismo e Espaço: rumo a um conhecimento transdisciplinar . $2^{\mathrm{a}}$ ed. São Paulo: Hucitec.

ROLNIK, R. (2010): Relatoria Especial da ONU para o Direito à Moradia Adequada e foi apresentada ao Conselho de Direitos Humanos.

SANTOS, M. (1997): Espaço e Método. $4^{\mathrm{a}}$ ed. São Paulo: Nobel.

SANTOS, N. and GAMA, A. (2008). "Os espaços/tempos de lazer na sociedade de consumo contemporânea”. In: Santos, N. e Gama, A. (Orgs). Lazer. Da Libertação do Espaço à Conquista das Práticas. Imprensa da Universidade de Coimbra, pp. 115-126.

SANTOS, N. (2014): "Turismo e Cidades: Conhecer o turista para valorizar a oferta do turismo cultural urbano". In: Lúcio Cunha e Rui Jacinto (Orgs.) Paisagens e Dinâmicas Territoriais em Portugal e no Brasil. Ed. Âncora, Lisboa, pp. 451-477.

SELLTIZ, C., JAHODA, M., DEUTSCH, M. and COOK, S. W. (1974): Métodos de pesquisa nas relações sociais. 2.ed. São Paulo, Editora Pedagógica e Universitária.

SIQUEIRA, M.T. (2014): "Entre o fundamental e o contingente: dimensões da gentrificação contemporânea nas operações urbanas em São Paulo". Cad. Metrop., São Paulo, vol. 16 (32), pp. 391-415.

SLATER, T. (2003): "Gentrification of the City". In: Bridge, G. and Watson, S. (Eds.) A Companion to the City, Malden, Blackwell.

URANI, A. (2009): "Salto Qualitativo na Retomada do Desenvolvimento". Jornal dos Economistas. Dezembro, no 245, pp. 5-6.

VALE EM FOCO. (2016): "Prefeitura do Rio de Janeiro esconde favelas com tapumes personalizados". Accessed on 12/12/2016 and Available at: http://valeemfoco18.blogspot.pt/2016/07/prefeitura-do-rio-de-janeiro-esconde.html

WEBER, R. (1985): Basic Content Analysis. Bervelly Hills, CA: Sage.

ZIMBALIST, A. (2010): "Is It Worth It? Hosting the Olympic Games and other mega sporting events is an honor many countries aspire to-but why?" Finance \& Development. March, pp. 8-11. 
